\title{
Editorial
}

\section{Increasing Muslim contribution to medical research; reviving a lost legacy}

\author{
ARA Rashid*
}

\section{Muslims' contribution to medical research in the past}

For almost 1 millennium the Islamic world was the most advanced and civilized place on the face of the world ${ }^{1}$. The main reason for this was the emphasis Islam places on the importance of and respect for knowledge, including the insatiable desire to gain knowledge from various sources. Muslim scholars translated the entire essential Greek, Syriac, Pahlavi, and Sanskrit medical and other writings into Arabic. The Muslims not only translated the works of previous civilizations, they generated new scientific knowledge by conducting research in various fields especially medicine ${ }^{2}$. The impact of Islamic civilisation on Western science, technology, and medicine between the years 800 and 1450 cannot be ignored. Despite earlier denial, the pioneering works of Muslim scientist are now being acknowledged even by Western scientist writing in mainstream journals ${ }^{3}$. Indeed, the Western world as we know it now might look very different without the legacy of Muslim scholars.

Unfortunately the great Islamic civilisation constructed by the Arabs went into decline $^{4}$. The flow of technology, research and development from the Islamic world to the West gradually slowed down and ultimately completely reversed in the past 600 years $^{5}$. Various reasons have been put forward to explain this dramatic decline and reversal of fortune ${ }^{6}$. These includes the political instability which engulfed the Muslim world, the subsequent compartmentalization of knowledge, natural disasters afflicting the Muslim world, attacks from external enemies and the rise of colonial Europe as a world power. Probably the deadly blow came from disunity among Muslims themselves.

\section{Status of contemporary Muslim contribution in medical research}

While it is inevitable that Muslims have the sense of pride with the contributions of their forefathers, they have to face the bitter truth; they currently lack behind the rest of the world with regards scientific advancement. The colonization of the Muslim world, which preceded the fragmentation and eventual demise of the Ottoman Caliphate, was the culmination of centuries of decline. During the era of colonization, Muslims were made to look and feel inferior viz a viz the superiority of the Western colonizers. It was also to the interest of the colonizers to sustain this inferiority complex within the psyche of their colonial subjects. Whatever potential which emerged from the Muslim colony were quickly capitalized, and brought into the Western fold. A case in point is an aspiring Indian Muslim surgeon Sheikh Din Muhammad who migrated to Ireland married an Irish lady and converted to Christianity changing his name to Sake Dean Mahomed ${ }^{7}$. Although he did not contribute to any major contributions to medicine, his grandson, Frederick Akbar Mahomed made major contributions. As a young doctor at the end of the $19^{\text {th }}$ Century, he invented an instrument which was 100 years ahead of his time. The instrument called a sphygmogram can accurately trace the radial pulse waveform and base on the waveform be used to diagnosed disease of the arterial system. His work has recently been revived with great interest to the modern medical scientific community ${ }^{8}$. 
In the latter half of the 20th century, Muslims countries were granted independence by their colonial masters. More recently, Muslim contribution is better acknowledged even by mainstream western media. However the contributions of the Muslims are portrayed as invention of an 'ancient world' with only peripheral significance to modern science. After gaining independence, many Muslim scientists had to travel to the West to pursue undergraduate and later post graduate studies due mainly to the lack of adequate infrastructure in their newly independent homeland. Many successful researchers and high achieving professionals among the Muslims decided to stay in Western countries for the same reasons; their own countries may not be able to support their career pathway for more scientific achievements. In the field of cardiovascular medicine for example Muslim researchers with major and significant contributions are mainly from South Asia. Names such as Salim Yusof, Hamid Ikram and Shahabuddin Rahimtoola are contemporary giants who are world famous. All had to ply their trade and expertise in the West, primarily in North America. In 2009, Shahabudin Rahimtoola (a graduate of Karachi University) was awarded the European Society of Cardiology Gold Medal Award for his lifelong contribution in the field. Indeed in the field of cardiovascular medicine, the Islamic legacy is still very much palpable ${ }^{9}$. Prominent Muslim physician scientists have also held very important and prestigious positions not just in cardiovascular medicine. Arguably the most notable being the immediate past director of the National Institute of Health $(\mathrm{NIH})$ in the United States of America, Dr. Elias A. Zerhouni, a world renowned radiologist and former vice dean of Johns Hopkins School of Medicine.

Excellent individual Muslim residing in West aside, how have Muslim nations fared in their contemporary contributions to medical research? A search of credible data bases such as the Medline showed a stark reality which we all would like to improve on. For example in 2005 there were altogether 35,431 cited publications from 6 Muslim countries (Indonesia, Pakistan, Egypt, Iran, Saudi Arabia, and Malaysia). This total is only slightly more than that of a small European nation, Netherlands $(35,027)$ and less than $10 \%$ that of the United Kingdom $(372,243)$ while the United States is even far ahead (1, 529,164). A sizeable contribution made by the United States emanates from work done by Muslim scientists working there. However on a positive note there has been close to a tripling of published research output from these Muslim nations by 2009 (94,034). While this is encouraging, we as a nation still lag behind the non Muslim nations. For example over the same period, the Netherlands has increased their output by 6 fold (to 220,123). Israel meanwhile published more than all the six Muslim countries put together $(111,842)$. This represents a 9 fold increase from their output in 2005 (18,217). Since most of the published work originated from institutions of higher learning this state of affairs may be reflective of the state of such institutions in the Muslim world. Indeed the latest Times Higher Education Survey showed that none of the universities in the Muslim world ranked in the top 100, the highest being the University of Malaya in Malaysia at a lowly $180^{10}$. In fact the University of Malaya is the only university from a Muslim country which is listed in the top 200. This in turn is a reflection of priorities given to research funding in most Muslim countries.

Not only are Muslims despondent at the relative lack of Muslim contributions to research and knowledge generation, even the non Muslims are asking the question ${ }^{11}$. Some have even proposed ways for the Muslims to reform themselves ${ }^{12}$. Others are perplexed as to why despite such a strong heritage in science, why are 
Muslims lagging behind ${ }^{13}$. As an ummah we have to answer the questions being asked of our conviction and rise up to the challenge of reliving our glorious distinguished past. We should not just lay on our laurels and singing the same old mantra about how great we were in the past. We have to face the stark reality that we are way behind in contemporary setting. We should also stop blaming everything on Western conspiracy theories. Adopting an attitude of 'Western phobia' and 'Western bashing' does not help either. We must strategise to bring back the glorious past.

\section{Strategies to revive Muslim's contribution to medical research}

What is required in the Muslim world is no less than a major transformation in order for us to return to our glorious past. It is important to begin with the end in mind and think long term. Clear end points or outcomes must be identified and this outcome extrapolated in the reverse direction to present day situation. This will provide an opportunity to recognize immediate requirements in the present system to reach the identified end point. Major barriers and hurdles must also be anticipated and strategies to circumvent them thought of. Any major transformation must be done in an integrated and collective approach. Muslim nations should work together towards this noble goal. This obviously is a tall order based on our track record in tackling common issues in the recent past. However the Muslim scientist community should not be disheartened and take this as a collective challenge. Indeed Muslim scientist and researchers can play a major role in regaining the credibility of the ummah by producing quality research which is universally acknowledged. By so doing the 'izzah (dignity) of the ummah can be partially restored, inshaAllah.

Listed below are the desired end points which we, especially those in academia should strive towards. The overall aim of targeting these end points is to create respectable Muslim Medical Institutions which are capable of generating respectable research output. There are essentially two main components: inculcation of research culture and inculcation of Islamic values among Muslim Medical Institutions. These two components must be addressed concurrently. It is beyond the scope of this editorial to elaborate on the proposed strategies. A more detail discussion on this has been articulated by the author and two other colleagues in an article in the most recent FIMA year Book ${ }^{14}$.

The Federation of Islamic Medical Association (FIMA) is an umbrella body of more than 40 members and associate members comprising of national Islamic Medical Associations. Since its inception in 1981, FIMA had embarked on many humanitarian activities, some of which received international acclaim. Another emerging initiative under FIMA is the Consortium of Islamic Medical Colleges (CIMCO) ${ }^{15}$. This Consortium launched in April 2000 with its mission to advance knowledge, foster collaboration, improves medical education and by so doing improving patients quality of care. CIMCO aspires to revive the glorious Islamic Era of the past through medical education, and research with the concept of Ihsan (excellence) as the driving force. Ihsan is an attribute expected of Muslims in all spheres of life as prescribed by Almighty Allah $^{16}$. It is this apparent lack of conviction to Ihsan which partially explains the current state of Muslim contributions in medical research. Any initiative to relive the glorious Islamic Era in general and medical research in particular requires strong conviction towards Ihsan among the Muslims and dedicated leadership to facilitate this through. What CIMCO hopes to achieve is to play that leadership role by facilitating networking and encourage Muslim medical 
researchers to share expertise and forge strong alliance towards achieving Ihsan in medical research. It is important that Muslim medical researchers with achieving Ihsan in mind galvanise efforts to work within the Islamic framework.

\section{Desired end points: respectable research output from Muslim medical institutions}

- Publications in Medical Research Journals of International Repute

- Publications of Medical Books from Muslim Authors
- Establishment of Centres of Excellence in Medical Research in Muslim countries

- Formation of International Research Collaborations between Muslim Medical Institutions and other international medical institutions of repute

- Formation of Industrial Research Collaborations between Muslim Medical Institutions and various health related industries

- Medical Research Fairs and Conferences with involvement of International Medical Community

\section{References:}

1. Ibrahim B. Syed. Islamic Medicine: 1000 years ahead of its times. http://www.islamfortoday.com/athar04.htm. (Accessed 4/7/2010).

2. Yasmeen Mahnaz Faruqi. Contribution of Islamic Scholars to the scientific enterprise. International Education Journal 2006, 7(4): 391-399.

3. West JB. Ibn al-Nafis, the pulmonary circulation and the Islamic Golden Era. J Appl Physiol 2008 Dec 105(6):1877-1880.

4. Ali A Allawi. The Crisis of Islamic Civilisation. Yale University Press, 2009.

5. Bulliet R. The case for Islamo-Christian civilization. Irvington, NY: Columbia University Press, 2004.

6. M Umer Chapra Muslim Civilisation; Causes of Decline and the Need for Reform. Leceister, The Islamic Foundation, 2008.

7. Ansari, Humayun. The Infidel Within: The History of Muslims in Britain, 1800 to the Present, C. Hurst \& Co. Publishers, 2004.

8. O'Rourke, Michael F. "Frederick Akbar Mahomed", Hypertension. 1992; 19: 212-217.
9. Turgut O, Yalta K, Tandogan I. Islamic Legacy in Cardiology: Inspirations from the Holy Sources. Int J Cardiol 2009 Oct 24. Epub ahead of print.

10. Times Higher Education - QS World University Ranking 2009. http://www.timeshighereducation.co.uk/ (Accessed on 2/1/2010).

11. Herwig Schopper. Islam and Science: Where are the new patrons of science? Nature 2006; 447 (7115):35-36.

12. Fergany N. Islam and Science: steps towards reform. Nature 2006; 444 (7115):33-34.

13. Butler D. Academies wrestle with issue of Islam's flagging science base. Nature 2003; 422(6928):101-102.

14. Tayyab Hassan, Afshan Shazad, Abdul Rashid Abdul Rahman. Muslim Contribution to Research; Past, Present and Future in FIMA Year Book 2009, Amman (in press).

15. http://www.cimco.org.

16. An Nawawi Forty Hadith, Hadith 17, Islamic Book Services, 2009. 